IZABELA SEKŚCIŃSKA ${ }^{1}$

DOI: $10.15290 / C R .2020 .31 .4 .04$

Łomża State University of Applied Sciences

ORCID: 0000-0002-9974-0513

AGNIESZKA PIÓRKOWSKA ${ }^{2}$

Łomża State University of Applied Sciences

ORCID: 0000-0003-4890-8790

\title{
Does Brexit
} mean Brexit?

\section{An analysis of the semantic field of the lexeme Brexit}

\begin{abstract}
The article presents the results of a discourse analysis of the contextual uses of Brexit. ${ }^{3}$ Based on corpus-driven Internet samples, the research employs the method of semantic field analysis devised by Robin (1980) and her team of researchers from the Saint-Cloud Political Lexicography Center. According to Robin, in order to find the meaning of a word, the context of its use must be analysed, as well as its lexical relations with other linguistic units. For this reason, we have divided the elements of the co-text of the lexeme Brexit into six groups, which represent various connections of linguistic items with the SUBJECT, i.e. the lexeme under scrutiny. Subsequently, in compliance with Kłosiński's approach (1994), we propose the definitions of the SUBJECT which reflect the meanings featuring the actual usages of the lexeme Brexit and which integrate the key words from the semantic field of the concept in question.
\end{abstract} Keywords: Brexit, semantic field, corpus, context, definitions.

\section{Introduction}

The term Brexit, or rather Brixit, as it was used initially by the financial press in 2012, stands for Britain's exit from the EU and is a blend of an adjective and a noun (cf. Davis 2017;

1 Address for correspondence: Wydział Nauk Społecznych i Humanistycznych, Państwowa Wyższa Szkoła Informatyki i Przedsiębiorczości w Łomży, ul. Akademicka 14, 18-400 Łomża, Poland. E-mail: isekscinska@pwsip.edu.pl

2 Address for correspondence: Wydział Nauk Społecznych i Humanistycznych, Państwowa Wyższa Szkoła Informatyki i Przedsiębiorczości w Łomży, ul. Akademicka 14, 18-400 Łomża, Poland. E-mail: apiorkowska@pwsip.edu.pl

3 Please, note that the article had been prepared for publication before Brexit came to fruition. 
Fontaine 2017). Chosen as the word of the year 2016 by Collins Dictionary (Stolworthy 2016), Brexit entered the Oxford English Dictionary (the OED henceforth) as early as in November 2016 (Line 2016). ${ }^{4}$ The OED offers a more detailed account of the phenomenon as it provides a twofold meaning. First and foremost, Brexit is regarded as "the proposed withdrawal of the United Kingdom from the European Union, and the political process associated with it" and, secondly, the term is used "with reference to the referendum held in the UK on 23rd June 2016, in which a majority of voters favoured withdrawal from the EU" (ibid.).

The dictionary meaning of Brexit can be detected in Theresa May's catchphrase "Brexit means Brexit", which was followed by her forceful promise: "we are going to make a success of it. There will be no attempts to stay within the EU [...] we must leave the EU" (Cowburn 2016). However, with the departure process extending over a prolonged period of time, the word Brexit has gained new meanings. Brexit no longer means only the scheduled withdrawal from the EU but may also be used as a verb to refer to "the act of telling everyone at a gathering (party, meeting, etc.) that you are leaving but actually staying” (Web 2), or as a cat's name to describe the cat's indecisive nature (Stone 2019).

Brexit discourse is often imbued with emotionally-charged expressions that betray speakers' attitudes, opinions and feelings towards this political event. This affective meaning inherent in the semantics of the lexeme Brexit is not, however, reflected in the dictionary entry. The dictionary meaning of the word seems to be semantically impoverished as it does not show that BREXIT is a sharply polarized concept, which everyday language use clearly indicates. We aim at providing a thorough definition of Brexit that is based on the actual uses of the analysed word and which can be found in pieces of knowledge about Brexit gathered from individual language users. Part of the purpose of the paper is also to evaluate Robin's method of semantic field analysis (Robin 1980) and to test its applicability to linguistic research. Though not well-known within the field of language study, Robin's approach seems to constitute a useful tool for linguistic analysis as it emphasizes the importance of context in the meaning of a lexical item, which is also the case in Cognitive Linguistics. Robin's (1980) syntagmatic approach to meaning appears to be consistent with the assumptions of Cognitive Linguistics, according to which "there are no stable word meanings, rather meanings of words are dynamic, context-sensitive and construed on-line" (Paradis 2012: 3357). Due to limitations of space, only Robin's method of semantic field analysis will be discussed in detail and contrasted briefly with the cognitive approach to lexical meaning.

\footnotetext{
4 More recently, Brexit has been announced the 2019 Children's Word of the Year as a result of a competition hosted by BBC Radio 2 Breakfast Show in partnership with Oxford University Press. The analysis of children's short stories submitted for the competition revealed that the use of the word increased by 192 percent since the 2018 competition. Frequently, children used the word as inspiration for inventing new names for different types of leaving, e.g. clexit 'class leaving the school' (Web 1).
} 


\section{Semantic field analysis by Régine Robin (1980)}

Similarly to Firth (1935: 37), who claims that "the complete meaning of a word is always contextual, and no study of meaning apart from a complete context can be taken seriously", Robin (1980) emphasizes that the meaning of a word cannot be studied in isolation from other linguistic elements. She defines the semantic field of a word as a network of lexical items which co-occur in real-world situations and which influence and contribute significantly to the meaning of the key element, i.e. the SUBJECT (Robin 1980). The hub of the entire network is the analysed word, which is either syntagmatically or paradigmatically related to other linguistic elements in the network. Robin (1980) suggests that the linguistic elements be divided into six different categories, but that any necessary changes to the classification of lexical items can be introduced if need be. According to Robin (1980), linguistic samples should be grouped as follows:

i. equivalents - expressions synonymous to the key word;

ii. oppositions - antonymous expressions;

iii. descriptions - expressions which are used to characterise the term in question;

iv. associations - words which are somehow connected with the key term;

v. actions of the SUBJECT - what the SUBJECT, i.e. the analysed word, does or what impact it has upon other entities, etc.;

vi. actions towards the SUBJECT - how the SUBJECT is influenced/affected; what actions are performed upon the SUBJECT, etc. ${ }^{5}$

All those linguistic elements constitute the semantic field of a given lexical item and contribute to the meaning of the key term, the definition of which can be worded, in keeping with Kłosiński’s (1994) proposal, in the following vein:

THE LEXEME UNDER SCRUTINY (i.e. THE SUBJECT), that is

[equivalents], as opposed to [oppositions], is described as [descriptions].

It is associated with [associations], causes/makes/performs [actions of

the SUBJECT] and undergoes/is subject to [actions towards the SUBJECT]. ${ }^{6}$

In the convention used:

ALL CAPS are used for the SUBJECT of the analysis;

italics are used for corpus data;

italics in bold are used for conjunctions;

5 Translation by the authors.

6 Translation by the authors. 
bold font (to occur in the Brexit definitions) is used for extra commentary of the authors resulting from the contexts in which the corpus examples appeared or were deemed necessary for stylistic purposes, but never interfering with the original meanings.

Kłosiński's suggestion, pursuant to Robin's postulate, to employ the expressions coded in particular relational networks so as to construe the broad and aspectual definitions of the term under scrutiny, is open to modification depending on the requirements of individual analyses (see the discussion in Fatyga et al. 2014: 2). ${ }^{7}$ Fatyga et al. (ibid.) claim that Robin's method is a flexible analytic tool and, while adapting it for their study of public discourse on copyright, they added to it an evaluation of the emotional temperature of linguistic expressions that co-occur with prawo autorskie 'copyright'. They assign the samples into four groups: positively-charged expressions, negatively-charged expressions, neutral and ambivalent expressions. In doing so, they refer to the psychological notion of affect, which is an integral part of human attitudes and can be defined as an elementary assessment of the state of affairs with reference to the positive-negative scale.

In our analysis, we embrace the alterations of both Kłosiński (1994) and Fatyga et al. (2014) and as a result, apart from the main definition of Brexit, we put forward two emotionally-marked definitions which synthesize the co-text expressions of Brexit that involve positive and negative attitudes, respectively (see the discussion in Section 5). Prior to this, we provide a detailed classification of the corpus samples based on the application of Robin's method (see Section 4). Each category into which lexical co-items of the key word were classified is briefly characterised and illustrated by means of selected examples from the corpus. The summary of the data collection procedure, as well as a brief description of the corpus is provided in the following section.

\section{Data collection procedure and the characteristics of the corpus}

The present study is a qualitative corpus analysis for which linguistic samples have been retrieved via WebCorpLive which, as is stated on the website (Web 3), "allows access to the World Wide Web as a corpus - a large collection of texts from which facts about the language can be extracted" (2019-09-06). WebCorpLive allows its users to find a word or a phrase in its own textual environment by means of such search engines as FAROO, Bing and The Guardian Open Platform. It generates concordance lines which show every occurrence of a particular word/phrase in the corpus on a single results page.

The authors of the paper used FAROO search engine as it operates on peer-to-peer technology to crawl the World Wide Web and provides a real-time search. All FAROO users contribute to the world-wide peer network, and the ranking of results is based

7 Cf. Paul \& Kisilowska (2016); Ziarko (2017). 
on user behaviour tracking and the popularity of webpages. The more often a web page is visited by FAROO users and the more time they spend browsing a given page, the higher in rank the webpage is. The linguistic data extracted by means of a distributed search engine appear to reflect browsing habits of FAROO users - there is no optimisation or positioning involved, which influence the visibility of a website or web page in popular centralised search engines.

The search was conducted on April 8, 2019. Limited to the English language, the case insensitive search generated 2060 concordances showing the word Brexit in the context of 100 characters. WebCorpLive successfully accessed 92 web pages and 15 websites. Wikipedia.org and youtube.com generated the greatest number of concordances as these are the pages which are the most frequently visited sites not only by FAROO users. ${ }^{8}$ Table 1 shows the distribution of concordances between the visited websites. It is important to underline that, as far as youtube.com is concerned, the search took into account only the written language, i.e. titles, descriptions of films, comments made by viewers, etc. Apart from wikipedia.org, and youtube.com, pages such as dailymail.co.uk, news.yahoo. com or bbc.co.uk were also searched, to find the word of interest, i.e. Brexit. The least frequently visited websites were telegraph.co.uk, theguardian.com, and mashable.com.

Table 1. The distribution of concordances between the websites

\begin{tabular}{|l|l|c|c|}
\hline No. & \multicolumn{1}{|c|}{ Website title } & $\begin{array}{c}\text { Number } \\
\text { of concordances }\end{array}$ & $\begin{array}{c}\text { Concordance } \\
\text { percentage }\end{array}$ \\
\hline 1 & bbc.co.uk & 87 & $4.22 \%$ \\
\hline 2 & bbc.com & 54 & $2.62 \%$ \\
\hline 3 & cnbc.com & 26 & $1.26 \%$ \\
\hline 4 & dailymail.co.uk & 167 & $8.11 \%$ \\
\hline 5 & en.wikipedia.org & 718 & $34.85 \%$ \\
\hline 6 & express.co.uk & 72 & $3.50 \%$ \\
\hline 7 & mashable.com & 14 & $0.68 \%$ \\
\hline 8 & nakedcapitalism.com & 29 & $1.41 \%$ \\
\hline 9 & news.yahoo.com & 89 & $4.32 \%$ \\
\hline 10 & nytimes.com & 21 & $1.02 \%$ \\
\hline 11 & reuters.com & 67 & $3.25 \%$ \\
\hline 12 & telegraph.co.uk & 12 & $0.58 \%$ \\
\hline 13 & theguardian.com & 14 & $0.68 \%$ \\
\hline
\end{tabular}

8 According to SimilarWeb ranking of the biggest websites based on the number of visits in June 2019, youtube.com is the second largest and Wikipedia.org is the fifth largest website in the world (Routley 2019). 


\begin{tabular}{|l|l|c|c|}
\hline No. & \multicolumn{1}{|c|}{ Website title } & $\begin{array}{c}\text { Number } \\
\text { of concordances }\end{array}$ & $\begin{array}{c}\text { Concordance } \\
\text { percentage }\end{array}$ \\
\hline 14 & xinhuanet.com & 24 & $1.17 \%$ \\
\hline 15 & youtube.com & 666 & $32.33 \%$ \\
\hline \multicolumn{2}{|l}{} & 2060 & $100.00 \%$ \\
\hline
\end{tabular}

The first mention of the word Brexit in the generated corpus dates back to January 1, 2016. The number of concordances appears to correspond to political events, and therefore, in the years 2016 and 2019, a significant increase in the interest in Brexit-related issues can be observed. The majority of concordances occurred in texts published in 2019 - 1619 (78.59\% of all the concordances in the corpus) and in $2016-228$ (11.07\%). 2017 and 2018 saw a significant drop in matters pertaining to Brexit, as there are only 30 (1.46\%) and 85 (4.13\%) concordances from those years, respectively. For 98 concordances (4.76\%), the publication date remains unknown.

\subsection{Identifying the semantic field of Brexit}

The purpose of this section is to present the analysis of the semantic field of the concept BREXIT which was conducted in accordance with Robin's approach (1980). As advocated by Robin (1980), linguistic elements from the corpus have been assigned to appropriate categories and each group of words contributing to the meaning of Brexit is briefly described in the subsections below.

\subsection{Equivalents}

The network of equivalents of Brexit comprises a collection of expressions which relate to the meaning of the notion in question and includes: phrases that relate to the idea of the UK leaving the European Union, as illustrated by the examples in (1a); those expressions that additionally evoke the notion of time connected with the upcoming Brexit (see the examples in (1b); and those that apart from the basic meaning (cf. [1a]) carry an additional emotional/subjective ${ }^{9}$ component, as illustrated by the samples in (1c).

(1)

a. Leave; leaving the EU; Britain's withdrawal from the EU; the UK's exit; Britain's departure from European leaders; UK divergence from EU;

b. the planned withdrawal of the UK from the EU; the UK's scheduled exit;

c. the troubled plan for Britain to quit the EU; the confusing and deeply nightmarish hellstorm

9 By "subjective" we mean elements of discourse which concern "expression of self and the representation of a speaker's (or, more generally, a locutionary agent's) perspective or point of view", as worded by Finegan (1995: 1). 
that Britain's attempt to leave the EU has become; Britain's great exit; Britain's Great Escape; split with Europe.

\subsection{Oppositions}

The phrases identified as oppositions of Brexit were divided into two main groups. The first group constitutes expressions that are direct opposites of the term or indicate ideas opposite to leaving the EU, as the examples in (2) illustrate. The second group (see the data in [3]) comprises expressions which refer to various scenarios that Brexit is contrasted with: all types of alternative scenarios like Britain having another referendum in which people would reconsider their choices concerning staying in or leaving the EU, or Britain leaving the European Union without a deal because of Parliament's lack of acceptance of the withdrawal agreement negotiated by Prime Minister May.

(2) Remain; Remain +; Bremain; The remain inside the EU; continued membership; not leaving at all;

(3)

a. Norway-style soft Brexit and second referendum;

b. to have another vote on Brexit;

c. a no-deal Brexit; crashing out without a deal;

d. reveal Brexit plan B; arrive at a consensus Brexit plan within any future time frame;

e. rejecting a no-deal Brexit and failing to reach a consensus for any alternative options.

\subsection{Descriptions}

The description network, according to Robin (1980: 255), refers to a variety of means of characterising the SUBJECT. As for the way users of the English language characterise Brexit, expressions that show their negative attitude towards the phenomenon (see the examples in [4a]) clearly prevail over those that code the positive attitude (cf. [4b]). ${ }^{10}$ Negative assessment is also salient in a group of expressions that refer to the way Brexit was or is being handled, as illustrated by the examples in (4c).

(4)

a. Brexit was a mistake; Brexit is a bad idea; Brexit is bad from every single angle; a catastrophically stupid decision;

b. Brexit is good for working people; Brexit is a very big step; Brexit is the only sensible choice;

10 The terms "positive/negative evaluations" are used in the sense of Fries (1992: 25-56), who maintains that evaluations expressed, for example, by adjectives like good or bad require for their interpretation the concept of both a scale and understanding that speakers' assessments of this kind involve gradation. 
c. Brexit has been a story of party management over the national interest; It's like the playground; a comedy of errors; Brexit: malice or incompetence?

A large collection of words referring to Brexit are expressions, mainly adjectives, that describe the event with respect to the legal aspects of the British withdrawal from the EU and can be organized around two ideas: leaving with a deal or leaving without a deal. Brexit, in view of the deal scenario, is usually described as "orderly" or "soft" (see the data in [5a]). Expressions used to refer to Brexit without a deal tend to evoke the ideas of abruptness and volatility, as the instances in (5b) show.

(5)

a. soft Brexit; a "softer" Brexit; orderly Brexit; "slow Brexit";

b. a disorderly Brexit (without an agreement); an "accidental disorderly" no-deal Brexit; Worst-Case Brexit; hard Brexit; painful Brexit; a rapid Brexit; cliff-edge Brexit; a clean\# Brexit; blindfold Brexit;

c. the "have cake and eat it" mentality Brexit; cherry-picking Brexit; a Green Brexit; a red, white and blue Brexit; white Brexit.

The senses in (5c) are usages whose interpretation is metaphorically grounded. On the one hand, there are "have cake and eat it" mentality Brexit and cherry-picking Brexit, which both indicate the disapprobation of the attitude of the British towards the process. Namely, the British are often criticized for wanting their exit to be an escape from the problems of the EU without losing the privileges and benefits arising from the membership. On the other hand, there are "colourful" Brexit adjectives: a Green Brexit that stands for Brexit and its potential benefits for environmental protection in the UK; white Brexit that stands for a partial Brexit, with Britain retaining its membership in the UK customs union of a single market; or a red, white and blue Brexit that stands for an ambitious deal with the EU from which all British subjects shall benefit once it takes place.

\subsection{Associations}

Another group of expressions are items that belong to the association network of Brexit. By associations we mean syntagmatic relations motivated contextually (see Robin 1980: 254). The expressions classified as associations can be sorted in the following vein. First, a substantial number of corpus expressions are associations that relate to Brexit taking place (6a), or expressions associated with procedural difficulties in handling Brexit (6b). The latter idea is also present in (6c), but in the case of these associations, an additional focus is on the timeline of Brexit and the duration of the process. Following this, there is a variety of names that we consider to be associations relating to people engaged 
in Brexit or affected by Brexit, so that the group includes both people in favour of it and those against it (6d).

(6)

a. the Brexit referendum; the Leave campaign; the exit deal; "divorce bill";

b. consensus Brexit plan; toxic Brexit debate; the Brexit withdrawal agreement; impasse over Brexit; the betrayal of Brexit; trice-rejected divorce deal;

c. a B "flextension"; an extension to Brexit; a postponement of Brexit; a further Brexit delay;

d. a fan of Brexit; Brexit Ally; the EU "BREXIT" Illuminati; Leavers; adherents of the Leave campaign; ardent Brexiteers; Brexit camp; Brexit supporters; Mr Brexit; Remainers; Remoaners.

One of the more conspicuous groups of associations of the SUBJECT are phrases that bring to light the chaos and uncertainty prompted by Brexit. Consider the data in (7).

(7) rising Brexit uncertainty; to solve Brexit chaos; to escape Brexit troubles; to put lipstick on the pig of her Brexit mess.

Importantly, a whole set of expressions are associations that relate to all sorts of Brexitinduced consequences. Presented in (8), they are either corpus instances that show that Brexit is frequently associated with its impact (8a), or examples which more specifically relate to the impact of Brexit in the realm of economy and finance (8b). It has to be noted that the majority of these associations correspond to the downsides of Brexit.

(8)

a. the impact of Brexit on the EU; Britain's self-inflicted Brexit crisis; damage of Brexit to the British economy

b. the savings on Brexit; the financial benefits of Brexit; economic effects of Brexit; estimates of the cost of Brexit; the real price of Brexit.

\subsection{Actions of the SUBJECT}

In Robin's approach, two more groups of phrases relate to the verbal network: those which encode actions of the SUBJECT and those which encode actions towards the SUBJECT. According to Fontaine (2017: 8), Brexit is a complex nominal, the meaning of which "encodes both the meaning of exiting as an event and the cognitive meaning of who/what will be doing the exiting”. In view of the above characteristics, we decided that the actions of the SUBJECT can be divided into two groups: those which indicate that Brexit is an event, as in the case of the data in (9) and (10); and those which show that Brexit itself may be a trigger for various consequences, as in (11). Such a division 
of linguistic samples is based on the meaning of verbs which are used to convey information on Brexit actions/influence.

The neologism Brexit, as underlined by Fontaine (2017: 2), carries an event-oriented meaning and, therefore, it is said to occur, happen or take place (9):

(9) Brexit is taking place; Brexit may not happen; Brexit won't happen without a compromise on both sides; No-one thinks Brexit will work;

As illustrated by (10), the lexeme Brexit may also be considered in terms of accomplishments, which constitute a subtype of the event, in line with Wilhelm's (1999:45) observation that "accomplishments have an initiation point as well as an endpoint. They take a certain (long or short) time to be completed, and are not completed before this time has elapsed".

(10) Brexit could slip away as crunch week looms; Brexit could "slip through our fingers".

The actions of the SUBJECT, however, refer mostly to the consequences connected with Britain's withdrawal from the EU (see the examples in [11]). Although the actual leaving has not taken place in the time frame of this article being written, Brexit has already exerted considerable influence upon different spheres of human life, international politics, and European Union stability. 7.6\% of all the linguistic examples in which Brexit is used in the subject position and is the trigger for the actions described refer to the past, $31.6 \%$ to the present, and $60.8 \%$ to the future. Significant as it is, a great number of examples that are future-oriented express hypothetical situations, worries or threats. Fontaine (2017: 12) even underlines that this hypothetical meaning is "implicitly encoded in the term Brexit [... which] is not derived from the blend itself but from the context of situation and how it came to be coined".

The samples describing the impact of Brexit have been divided into four topic-related categories that include: political consequences of Brexit, the impact of Brexit on business, economy and finance, social consequences of Brexit, and other consequences. The corpus usages of the lexeme Brexit used in the subject position and catalogued within these four categories were most numerous among the data in the study and therefore, a limited number of them were selected for the sake of presentation (11).

$36.7 \%$ of all the samples describing Brexit as a cause of consequences can be interpreted as referring to political consequences of Brexit, mainly potential and anticipated. The group is illustrated with the examples in (11a). Equally, many corpus instances indicate consequences which are economic and financial in nature (11b). 13.9\% of the samples are concerned with the social consequences of Brexit, as some of them included below in (11c) show. Finally, 12.7\% of the samples are cases which were classified as other consequences of Brexit (11d). 
(11)

Brexit raised issues around sovereignty for Gibraltar; Brexit threatens Good Friday agreement; EU referendum: Brexit would spark "constitutional crisis" for UK;

a. Brexit has already hurt EU and non-EU exports; Brexit will redirect our nation's cash-flow; The no deal Brexit could create economic pain across Europe, with no winner;

b. Brexit poses challenges for UK higher education and academic research; "the Brexit destroys own country and people;"11 Brexit would deplete the National Health Service (NHS) workforce;

c. a no-deal Brexit would have dire consequences; a hard Brexit would deliver a shock; Brexit would result in a "lose-lose situation" for both the UK and the EU.

In all the examples listed above, the term Brexit is used in the subject position. However, there are also examples in which the action of the SUBJECT is implicitly conveyed. Brexit is frequently used as a noun modifier or part of a noun modifying phrase. As a result, it is not the Brexit as such that is the "causer" of certain actions but phenomena strictly related to it, and therefore, it is the Brexit referendum itself that damaged the economy, or the Brexit vote that may spark recession. Consider more examples in (12):

(12) Brexit-induced reductions in migration; Every move in the pound has been tied directly to Brexit news; The 27 are frustrated with all the Brexit wrangling.

Similarly, the data in (13) refer to a Brexit-induced impact with the lexeme Brexit featuring in these examples as a prepositional complement. In some cases, as in: What can America learn from Brexit?, Brexit itself is the phenomenon that leads to certain consequences. In others, however, as in: the country at large remains deeply polarised over the terms of Brexit and even whether to depart at all; Brexit is, in general, the factor leading to certain consequences.

(13) almost all UK regions are systematically more vulnerable to Brexit than regions in any other country; The end of British austerity starts with Brexit.

\subsection{Actions towards the SUBJECT}

For clarity, actions towards the SUBJECT have been divided into seven topic-related categories. They reflect external influence exerted upon the SUBJECT, i.e. what is done to Brexit or with Brexit, and how it is affected by some actions. Apart from the phrases in which Brexit is used in the object position, examples in which the key term functions

11 Our corpus contains non-standard usages of spelling and grammar of English, which we indicate with asterisks where necessary. 
as a noun modifier (NM) or a prepositional complement (PC) have been included as well, as they still describe actions directed at the SUBJECT.

First and foremost, Brexit is subject to actions which are either to prevent it from happening (14) or which are to ensure that it will take place (15).

(14) to unilaterally halt Brexit; to stop Brexit; take Brexit off the table and stay in the EU; "kiss goodbye" to Brexit (PC).

(15) leaving "no stone unturned" to try and resolve Brexit; to navigate Brexit; to nail Brexit; to secure Brexit; to have another vote on Brexit (PC).

Still other examples can be grouped on the grounds that they seem to indicate the awareness of the speakers as to the obstacles leading up to Brexit (16) or actions towards the SUBJECT that are destructive for it (17).

(16) There is now a danger that Brexit could be lost; Is May set for total Brexit surrender? (NM); to fail to deliver on Brexit (PC); there was a risk of Brexit slipping further from grasp (PC).

(17) destroying Brexit in the process; "terrible collaboration" between EU and UK MPS to HIJACK Brexit; Rees-Mogg ATTACKS PM for KILLING BREXIT.

While the examples in (17) show the negative or destructive impact upon Brexit, others contain verbs or phrases which signify that Brexit is a source of confusion and disagreement, as in (18) below:

(18) Brexit was sold through hysteria; *brits poke their eyes out with Brexit. They are a neverending Monty Python Show! (PC); Parliament wrestles with Brexit (PC).

With a global-scale impact, Brexit attracts a great deal of attention and its updates occur regularly. Hence, a significant portion of the corpus shows actions which are to influence the reception of Brexit or which inform about recent news releases. Consider the data in (19):

(19) Trevor Noah roasts Brexit using multiple British accents; Mark Blyth, who accurately predicted Brexit and Trump explains in clear language how globalisation and capitalism are failing people. 
Finally, the examples in (20) refer to the actual departure of Britain from the EU and, to be more specific, to the extension to the withdrawal date, often referred to as "Brextension":

(20) to delay Brexit; to kick Brexit a year more down the road; to postpone Brexit; a flexible Brexit extension (NM); to grant the UK more time over Brexit (PC).

\section{Definitions of Brexit}

On the basis of the corpus analysis and Kłosiński's (1994) formulation of the definition which stems from semantic field analysis (see Section 3 of the article), it was possible to arrive at a broad definition of Brexit. May's statement "Brexit means Brexit," in view of real language use, could thus be rephrased as follows:

\section{Definition 1:}

BREXIT that is Leave, the UK's scheduled exit, as opposed to Remain, continued membership but also in contrast to other alternative scenarios, such as not leaving at all, putting Brexit to a second referendum [...] with a view to cancelling it or to an "accidental disorderly" no-deal Brexit, rejecting a no-deal Brexit and failing to reach a consensus for any alternative options, is described both as a mistake and the only sensible choice, bad from every single angle and good for working people, as well as soft and hard, orderly and disorderly, either a success or a failure, green, white, or red, white and blue.

BREXIT is associated with its own proceeding, as in the Brexit referendum, the Leave campaign, a consensus Brexit plan, a series of Brexit options, the Brexit withdrawal agreement, a Brexit impasse, Brexit day, a flexible Brexit extension; BREXIT is also associated with the people engaged in the process, like Leavers, pro-Brexit members, pro-Brexiteers, Brexit-backing ministers, but also with hardline Eurosceptic Conservative lawmakers, or Remainers, as well as with its multiple consequences including the impact of Brexit on the EU, economic effects of Brexit, the real price of Brexit, Brexit uncertainty, Brexit chaos.

BREXIT happened and it has become so toxic; it sparks chaos, threatens to eat up more of the EU's time; it may not happen, or "slip through our fingers" as it won't happen without a compromise. BREXIT would have a "knock-on effect in Europe and in the world" and would result in a "lose-lose situation" for both the UK and the EU. It raises questions: if it could create a crisis at the Irish border; what the implications of Brexit for agriculture and farming will be; whether "Brits are going to be worse off" because of it; if our democracy is under threat over Brexit.

BREXIT undergoes actions which are to prevent it from happening, such as voting to cancel Brexit, stopping Brexit, taking Brexit off the table, or which are to ensure that it will take place, such as navigating Brexit, finding a way out of a Brexit impasse, arriving at a consensus Brexit plan or debating the way forward on Brexit. People are anxious about 
BREXIT, as in Brexit might not be delivered at all or could be lost as time is running out for Brexit to be secured. BREXIT is being sold through hysteria and surrounded in chaotic uncertainty and undergoes attacks which attempt to wreck it, thwart it, kill it, hijack or destroy it. Most of all, however, BREXIT is being debated, explained, updated, roasted, and spoofed, and the way it came about and has been prosecuted is a tragedy.

In analysing the corpus data, the next step was to sort linguistic samples into groups according to their emotional charge. Brexit discourse, especially the samples classified as "actions of the SUBJECT" and "actions towards the SUBJECT", appeared emotionally-marked to a large extent, covering extreme attitudes of the speakers towards the phenomenon, from fierce opposition to absolute approval with total disregard for the complications that Britain's withdrawal from the EU may result in.

In accordance with the suggestions of Fatyga et al. (2014), ${ }^{12}$ we divided the samples into four categories by assigning to them positive, negative, neutral or ambivalent values. The assessment was carried out in such a way that we focused on those elements of the utterances that indicated the speaker's subjective and intersubjective evaluations of the states of affairs, like expressions of emotional attitude, or boulomaic modality, which, according to Nuyts (2006: 12), is typically coded by means of lexical means such as predicative adjectives, adverbs, and the main verbs. In our data, positive or rather a positive attitude is illustrated by the samples in (21a), while those in (21b) exemplify neutral senses. Utterances such as those in (21c) and (21d) were interpreted as ambivalent and negative or rather negative, respectively. Let us note at this point that, after the convention of Nuyts, the expression of emotional attitude involves scalarity, with the speakers' opinions varying from absolute liking, through neutral, to absolute disliking. Therefore, we assume the boundaries between the categories below to be fuzzy, rather than clear-cut.

a. Brexit is causing summer package holiday prices to Europe to drop; to save Brexit;

b. Article 50 - the legal mechanism through which Brexit is taking place; to propose options for Brexit;

c. Brexit beckons; May offers to compromise on Brexit;

d. Brexit will hurt the economy; MPs voting to seize control of Brexit from ministers has only fuelled the demands.

In the case of the actions of the SUBJECT, the majority of the examples (65.5\%) exhibit mostly negative emotions. The neutral value was assigned in about one quarter

12 Cf. the discussion in Section 2. 
of the examples, while ambivalent or positive values were assigned in $5.5 \%$ and $4.8 \%$ of cases, respectively (see Figure 1 below).

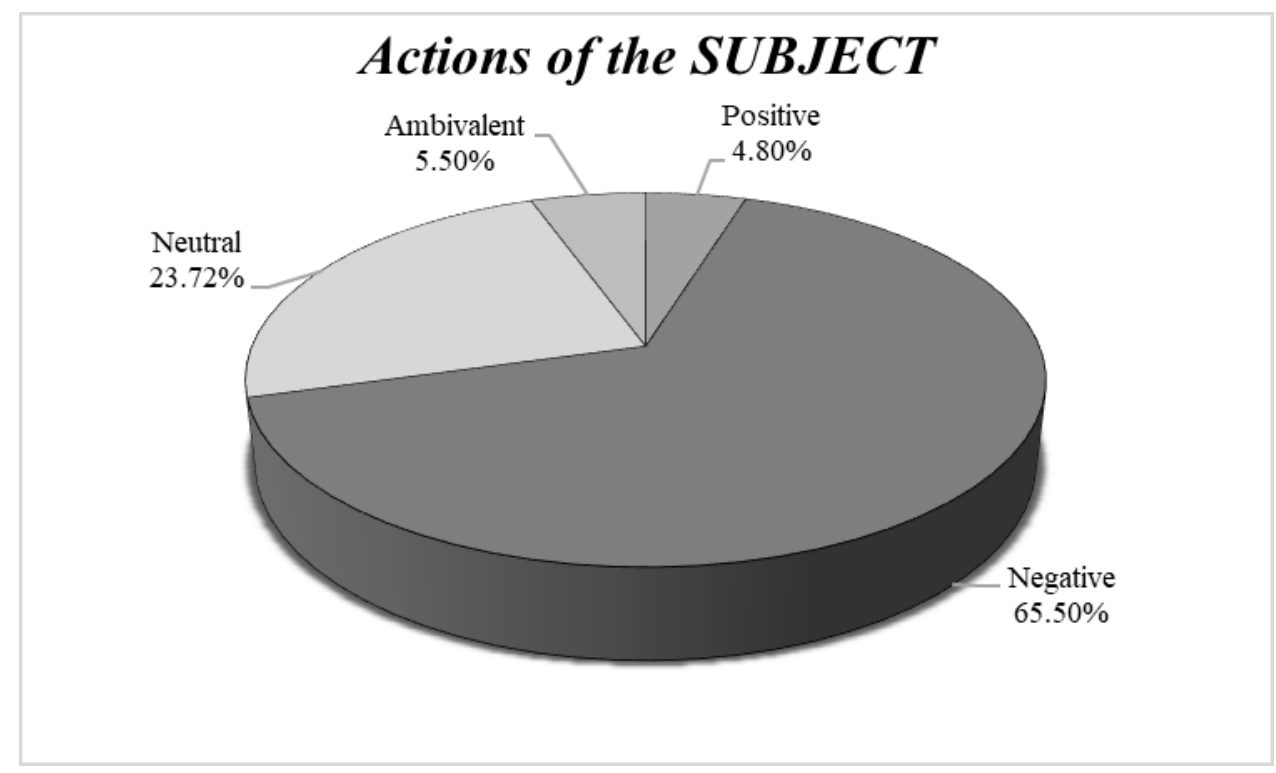

Figure 1. Emotional bias as exhibited by samples classified as "actions of the SUBJECT"

Likewise, actions towards the SUBJECT have been analysed according to their emotional charge. Figure 2 visualizes the division of linguistic examples into positive, negative, neutral and ambivalent, and gives their percentage distribution. From the pie chart, it is clear that the majority of examples are negative or neutral, with just $9.87 \%$ difference between the two. Only a small fraction of linguistic samples is positive (8.01\%) whereas $21.6 \%$ is considered ambivalent.

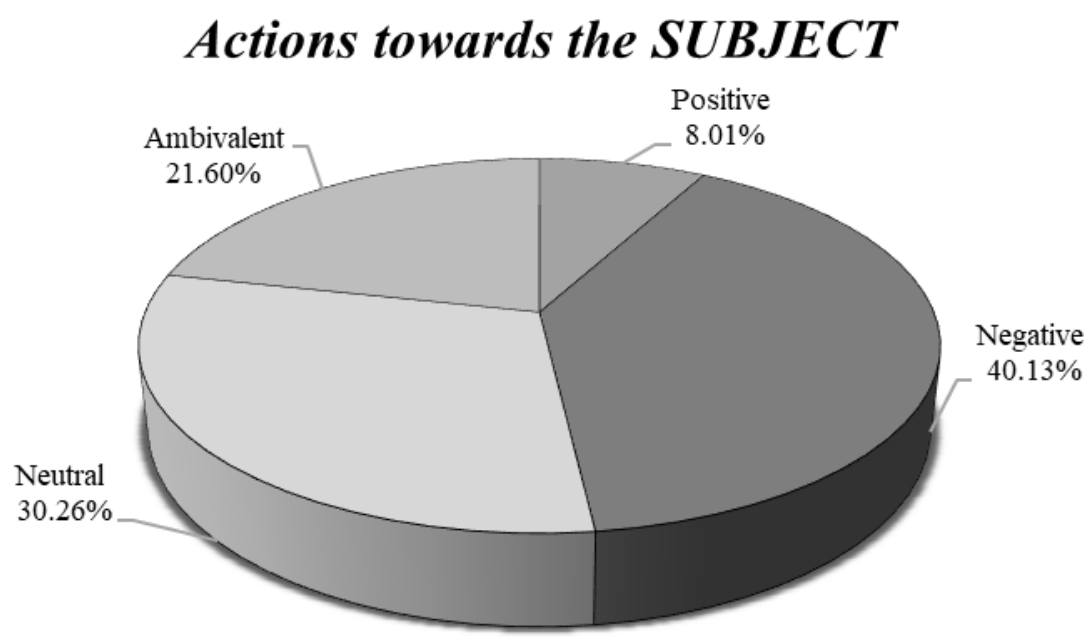

Figure 2. Emotional bias as exhibited by samples classified as "actions towards the SUBJECT" 
Taking into account the above considerations, the authors propose the formulation of two more definitions of Brexit, that is the positive one (see Definition 2) and the negative one (Definition 3). Depending on language users' experience with the phenomenon of Brexit, May's definition of Brexit could be completed in the following vein:

\section{Definition 2:}

BREXIT, that is the planned withdrawal of the UK from the EU, the UK's scheduled exit, Britain's Great Escape, as opposed to alternative options, such as Norway-style soft Brexit and second referendum, is described as soft, orderly, and good for working people. It is a very big step and the only sensible choice.

BREXIT is associated with its own proceeding, as in the Brexit referendum, the exit deal, a consensus Brexit plan, a series of Brexit options, the Brexit withdrawal agreement, and with the people engaged in the process, like a fan or supporter of Brexit, pro-Brexit members, pro-Brexiteers, as well as with its consequences which include the savings on Brexit, and the financial benefits of Brexit.

BREXIT will redirect our nation's cash-flow, and wages for British workers will rise in the event of Brexit. It is causing summer package holiday prices to Europe drop and the end of British austerity starts with Brexit.

BREXIT undergoes actions whose aim is to try and resolve Brexit (leaving 'no stone unturned'), to nail and agree on it, to conclude a Brexitdeal, or grant the country an extension to it.

\section{Definition 3:}

BREXIT, that is the troubled plan for Britain to quit the EU, the confusing and deeply nightmarish hellstorm that Britain' attempt to leave the EU has become, as opposed to alternative scenarios like rejecting a no-deal Brexit and failing to reach a consensus for any alternative options, crashing out without a deal; is described as a mistake, a catastrophically stupid decision, a story of party management over the national interest and a comedy of errors. It is hard, disorderly, painful, bad from every single angle, and it is like the playground.

BREXIT is associated with its own proceeding, as in the impasse over Brexit, the fundamental problem with Brexit, the betrayal of Brexit, trice-rejected divorce deal; with the people engaged in the process, like Remoaners, the EU "BREXIT" Illuminati and infuriated Brexit supporters, as well as with its consequences, as in Brexit uncertainty/chaos/mess or troubles; Brexit betrayal, budget cuts and damage to the British economy.

BREXIT, among other things, threatens to eat up more of the EU's time, while other issues demand attention; it will strengthen all authoritarians and would spark 'constitutional crisis' for the UK. It has already hurt EU and non-EU exports, and poses challenges for UK higher education and academic research as it could cost UK science millions in lost research funding. It will have immediate and longer-term effects on the economies of the UK and would have an adverse impact on health in the UK under every Brexit scenario as it would deplete 
the National Health Service (NHS) workforce. Brexit destroys own country and people and is damaging their brains.

BREXIT undergoes actions whose aim is to unilaterally halt Brexit or hijack and kill it; to reverse it, to stumble toward it or to destroy it. Brits poke their eyes out with Brexit, and people/politicians lash out over it, clash on it, roast or spoof it, and Parliament wrestles with Brexit, whereas MPs vote to seize control of it as they will not let Theresa May "surrender" to a soft Brexit. They talk about nothing else but Brexit, and the BBC is biased against it.

The definitions above reflect the extreme positions that speakers assume when expressing their assessment and attitude towards Brexit, and bring to light the political divide over the issue of Brexit. Apart from the dictionary meaning, they contain contextinferred elements of cultural knowledge, as well as personal experience-based knowledge of language users, who vary in their opinions of Brexit. Emerging from the analysis of real language use, the definitions show that the meaning of a concept is reliant upon other linguistic elements, and its semantic field reflects its network of relations with other contextually-bound lexical units. Hence, the word Brexit does not merely mean 'the British exit from the EU', but also, as definitions show, the scheduled exit or the planned withdrawal, and at the same time, Britain's Great Escape or the confusing and deeply nightmarish hellstorm. May's sentence: "Brexit is..." appears to have multiple endings because Brexit means something different for each of us, as the meaning of the concept is highly dependent upon our background knowledge and experiences with the term under discussion.

\section{Cognitive approach to the meaning of Brexit}

Similarly to the syntagmatic approach represented by Robin (1980), "the cognitive approach to meaning is usage-based" (Paradis 2012: 3357) and, as Evans and Green (2006: 160) emphasize, "words do not represent neatly packaged bundles of meaning (the dictionary view), but serve as 'points of access' to vast repositories of knowledge relating to a particular concept or conceptual domain”. This set of cognitive domains evoked by an expression is called a conceptual matrix by Langacker (2008), who also claims that it is essential to activate encyclopedic knowledge for proper understanding of a concept. In Langacker's vein (2008), the conceptual matrix for the word Brexit will thus incorporate such basic domains as SPACE, TIME and FORCE (Lakoff \& Johnson 1980), and some abstract domains which are reflected in metaphorical usages of the lexeme Brexit.

As the analysis of the Brexit corpus revealed, the term is largely used in negative contexts and is perceived mostly as a THREAT or DISASTER, which the selected examples in (22) and (23), respectively, demonstrate: 
(22)

Brexit is a threat

Brexit: the unexpected threat to peace in Northern Ireland.

Brexit will reinvigorate the Armageddon synonym industry by freeing it from the constraints of Brussels red tape.

Brexit would threaten Calais border agreement.

BREXIT IS A DISASTER

*The Brexit destroys own country and people.

Brexit would be a disaster for UK science, say scientists.

Almost all UK regions are systematically more vulnerable to Brexit than regions in any other country.

Never-ending Brexit talks, replete with sheer hatred and bile, turn the political scene into a battlefield, and Brexit appears to be the object of FIGHTING/WAR (24):

Brexit is fighting/war

I'm waiting for May to move Brexit "red lines".

She fought off a plot to delay Brexit.

The foreign secretary immediately went on the attack over Brexit...

Such mixed feelings over the UK's withdrawal permeate speech and language, in general, and influence public attitude towards the inevitable split with the EU. Interestingly, Brexit is not only perceived as a bone of contention but also as a VICTIM (25), which the following examples illustrate:

\section{Brexit is a victim}

May has wrecked Brexit, and wrecked the country.

May launched talks with him in a last-ditch bid to save Brexit.

May to BLAME: Rees-Mogg ATTACKS PM for KILLING BREXIT - All rests with HER!

Fierce disagreement over the terms of the withdrawal, verbal abuse among politicians, as well as bitter hostility between pro - and anti-Brexit protesters result in talking about Brexit in terms of CHAOS, as indicated by the examples in (26): 


\section{Brexit is chaos}

May attempted to put lipstick on the pig of her Brexit mess.

Britain's thriving art scene strangled by chaos.

The chaos over Brexit will likely have done irreparable damage to public confidence in our political system.

As is often emphasised, 23 June 2016 has changed the world forever and undermined European integrity. Brexit-resultant political and economic instability and insecurity are predicted to drag on for years, and the costs of Brexit are likely to increase significantly. Hence, Brexit is often portrayed metaphorically as a cosT, which is illustrated by the examples in (27):

\section{Brexit is a cost}

The real price of Brexit begins to emerge.

Brexit vote may spark recession.

Brexit will likely reduce the UK's real per capita income.

Brexit has been the buzzword on everyone's lips since the referendum, and "has inspired far more metaphors than it has solutions" (Tapper 2019). Compared to a cup of peppermint tea, escaping from prison, eating a chocolate orange, ordering at a restaurant, a divorce or failed marriage, Brexit refers to an excruciatingly prolonged process that is difficult to grasp or explicate, and which arouses long-standing controversy, which figurative language tends to illuminate. Though it is not our aim to analyse all the metaphors connected with the key term, we are convinced that it is worth mentioning just a few of them, as they undeniably bring to light certain aspects of the Brexit phenomenon. They provide a window into human cognition and reveal how people conceptualise and reason about this political phenomenon. The inductive approach to metaphor analysis enabled us to identify domains against which the concept is understood and characterised.

In contrast to Robin's method of analysis, which enabled us to arrive deductively at the definition of Brexit, the cognitive approach to semantics illuminates which bodies of knowledge are activated during the process of meaning construction. It concentrates mainly on the conceptual level, as opposed to Robin's, which focuses on the syntactic level of language and analyses linguistic samples which may have influence upon the meaning of a lexical item. Obviously, Robin's approach to lexical semantics cannot be treated on a par with Langacker's encyclopaedic view as they represent different, but not exclusive, approaches to the analysis of a word's meaning. However, it goes 
without saying that cognitive assumptions may contribute significantly to a deeper understanding of the key concept.

\section{Conclusion}

This paper set out to provide a definition of Brexit which resulted from the analysis of instances of the occurrences of the key term in the generated corpus. We adopted Robin's method of semantic field analysis to divide linguistic samples and made use of Kłosiński's (1994) and Fatyga et al.'s (2014) assumptions to provide a more thorough usage-based analysis of the lexeme Brexit. We also showed that, on the basis of the analysis of emotional temperature, apart from the broad - neutral definition, we may formulate positive and negative ones to present polar views about the term under discussion. Finally, we noted that the cognitive approach to lexical semantics may contribute significantly to the analysis of a word's meaning, as it brings to light aspects of encyclopedic knowledge that are essential for the concept to be properly understood.

Although Robin's approach seems to provide a well-designed division of linguistic samples, it is effortful and time-consuming and therefore, may be inappropriate for the analysis of large corpora. However, it seems quite useful for specifying synonyms, antonyms or collocations of a concept, or for determining grammatical features of a lexeme. In addition, Robin's analysis of semantic fields, applied together with Kłosiński's (1994) definition of the SUBJECT, reveals how the analysed concept is portrayed by language users and provides us with a compilation of views about the lexeme. As has already been posited, Brexit discourse is florid and emotionally loaded, frequently aggressive and disrespectful, and the term itself is largely used in negative contexts, the trend being well-captured in the positive and negative definitions of the lexeme that the authors develop.

\section{References}

Cowburn, A. 2016. Theresa May says 'Brexit means Brexit' and there will be no attempt to remain inside EU. https://www.independent.co.uk/news/uk/politics/theresa-maybrexit-means-brexit-conservative-leadership-no-attempt-remain-inside-eu-leave-europe-a7130596.html (3 September 2019).

Davis, G. 2017. The language of Brexit. https://www.open.edu/openlearn/languages/english-language/the-language-brexit (1July 2019).

Evans, V. \& Green, M. 2006. Cognitive Linguistics. An Introduction. Edinburgh: Edinburgh University Press.

Fatyga, B., Kietlińska, B., Michalczak, K., Michalski P., Piotrowski M. \& Tomanek, P. 2014. Raport końcowy z badania dyskursu publicznego o prawie autorskim w Polsce w latach 2012-2013. 
https://prawokultury.pl/media/entry/attach/Fundacja_Nowoczesna_Polska-Raport_ ko\%C5\%84cowy-Badanie_dyskursu_prawa_autorskiego.pdf (25 April 2019).

Finegan, E. 1995. Subjectivity and subjectivisation: an introduction. In: D. Stain \& S. Wright, (eds.), Subjectivity and Subjectification. Linguistic Perspectives, 1-15. Cambridge: Cambridge University Press.

Firth, J. R. 1935. The technique of semantics. Transactions of the Philological Society 34(1): 36-73.

Fontaine, L. 2017. The early semantics of the neologism BREXIT: a lexicogrammatical

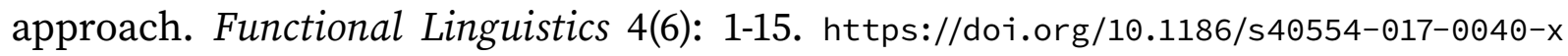
(15 January 2020).

Fries, N. 1992. Wartościowanie. Aspekty językowe i pojęciowe. In: G. Falkenberg, N. Fries \& J. Puzynina (eds.), Wartościowanie $w$ języku $i w$ tekście na materiale polskim i niemieckim. Warsaw: Wydawnictwa Uniwersytetu Warszawskiego.

Kłosiński, Marek. 1994. Semantyczna analiza pojęć ‘bezrobocie’ i 'bezrobotny' ('bezrobotni’) w wypowiedziach prasowych. Kultura i Społeczeństwo 3: 151-162.

Lakoff, G. \& Johnson M. 1980. Metaphors We Live By. Chicago: University of Chicago Press. Langacker, R. W. 2008. Cognitive Grammar. An Introduction. New York: Oxford University Press, Inc.

Line, H. 2016. Oxford English dictionary offers definition of Brexit as it adds new words. https://www.independent.co.uk/news/uk/home-news/brexit-definition-oxford-englishdictionary-add-new-words-2016-a7476271.html (6 September 2019).

Nuyts, J. 2006. Modality: Overview and linguistic issues. In: W. Frawley (ed.), The Expression of Modality, 1-26. Berlin/New York: Mouton de Gruyter.

Paradis, C. 2012. Lexical Semantics. In: C. A. Chapelle (ed.), The Encyclopedia of Applied Linguistics, 3357-3356. Wiley: Blackwell. https://doi.org/10.1002/9781405198431. wbeal0695

Paul, M. \& Kisilowska, M. 2016. Czym jest czytanie? Intuicje i definicje. Kultura Popularna 4(50): 16-34. http://bazhum.muzhp.pl/media//files/Kultura_Popularna/Kultura_Popularnar2016-t-n4_(50)/Kultura_Popularna-r2016-t-n4_(50)-s16-34/Kultura_Popularna-r2016t-n4_(50)-s16-34.pdf (12 December 2019).

Robin, R. 1980. Badanie pól semantycznych: doświadczenia Ośrodka Leksykologii Politycznej w Saint-Cloud. In M. Głowiński (ed.), Język i społeczeństwo, 252-281. Warsaw: Czytelnik.

Routley, N. 2019. Ranking the top 100 websites in the world. https://www.visualcapitalist. com/ranking-the-top-100-websites-in-the-world/ (8 September 2019).

Stolworthy, J. 2016. Collins Dictionary's 10 words of the year, from 'Brexit' and 'snowflake generation' to 'JOMO'. https://www.independent.co.uk/arts-entertainment/books/ news/collins-dictionarys-10-word-of-the-year-from-brexit-and-snowflake-generationto-jomo-a7395121.html (5 January 2019). 
Stone, J. 2019. France's EU minister names her cat 'Brexit' because 'he meows loudly to be let out but won't go through the door'. https://www.independent.co.uk/news/ world/europe/brexit-france-theresa-may-deal-nathalie-loiseau-cat-a8828026.html (4 September 2019).

Tapper, J. 2019. The many metaphors of Brexit. https://daily.jstor.org/daily-author/ james-tapper/ (1 January 2019).

Wilhelm, A. 1999. Event structure and syntax: German*. Calgary Working Papers in Linguistics 21(Winter): 44-65.

Ziarko, J. 2017. Framing w nowych mediach jako narzędzie manipulacyjnego oddziaływania na społeczeństwo, na przykładzie budowania dyskryminującego obrazu uchodźców. Bezpieczeństwo. Teoria i Praktyka 4: 65-83. https://btip.ka.edu.pl/ pdf/2017-4/btip2ఠ17-4-ziarko.pdf (26 January 2020).

\section{Web pages:}

Web 1 - BBC Media Centre. https://www.bbc.co.uk/mediacentre/latestnews/2019/childrens-word-of-the-year (19 January 2020).

Web 2 - Urban Dictionary. http://www.urbandictionary.com (21 December 2019).

Web 3 - WebCorpLive. http://www.webcorp.org.uk/live/guide.jsp (8 April 2019).

$$
* * *
$$

Izabela Sekścińska is a lecturer at Łomża State University of Applied Sciences. Her main teaching areas are descriptive grammar of the English language and comparative linguistics. She obtained her Ph.D. degree in linguistics from Nicolaus Copernicus University in Torun. Her current research is in the area of neuroscience and psycholinguistics.

Agnieszka Piórkowska holds a Ph.D. in linguistics, and works as a lecturer at Łomża State University of Applied Sciences. Her research interests include cognitive investigation of modality and emotional attitude, as well as methodology of teaching English to young learners. 